\title{
Crossbreds of Jersey $\times$ Holstein Compared with Pure Holsteins for Body Weight, Body Condition Score, Dry Matter Intake, and Feed Efficiency During the First One Hundred Fifty Days of First Lactation
}

\author{
B. J. Heins, ${ }^{1}$ L. B. Hansen, A. J. Seykora, A. R. Hazel, D. G. Johnson, and J. G. Linn \\ Department of Animal Science, University of Minnesota, St. Paul 55108
}

\begin{abstract}
Jersey $\times$ Holstein crossbred $(\mathrm{J} \times \mathrm{H})$ cows $(\mathrm{n}=24)$ were compared with pure Holstein cows $(\mathrm{n}=17)$ for body weight, body condition score, dry matter intake (DMI), and feed efficiency during the first $150 \mathrm{~d}$ of first lactation. Cows were housed in the University of Minnesota dairy facility at the St. Paul campus and calved from September 2004 to January 2005. The $\mathrm{J} \times \mathrm{H}$ cows were mated by artificial insemination with Montbeliarde bulls, and Holstein cows were mated by artificial insemination with Holstein bulls. Cows were weighed and body condition was scored every other week. Cows were individually fed a TMR twice daily, and feed refusals were measured once daily. The DMI of cows was measured daily and averaged across 7-d periods. Milk production and milk composition were from monthly Dairy Herd Improvement records. Best Prediction was used to calculate actual production (milk, fat, protein) for each cow from the 4th to 150th day of first lactation. The $\mathrm{J} \times \mathrm{H}$ cows had significantly less body weight (467 vs. $500 \mathrm{~kg}$ ) and significantly higher body condition scores (2.90 vs. 2.76 ) than pure Holstein cows. The $\mathrm{J} \times \mathrm{H}$ cows had significantly less milk production $(4,388$ vs. $4,644 \mathrm{~kg}$ ) during the 4 th to 150 th day of lactation than did pure Holstein cows. However, fat plus protein production during the first $150 \mathrm{~d}$ of lactation was not significantly different for $\mathrm{J} \times \mathrm{H}(302 \mathrm{~kg})$ and Holstein $(309 \mathrm{~kg}$ ) cows. The $\mathrm{J} \times \mathrm{H}$ and pure Holstein cows did not differ significantly for daily DMI (22.0 vs. $22.7 \mathrm{~kg}$, respectively), and the $\mathrm{J} \times \mathrm{H}(4.7 \%)$ and pure Holstein (4.5\%) cows consumed similar DMI based on percentage of body weight. Consequently, feed efficiency for the 4 th to 150th day of lactation did not differ for $\mathrm{J} \times \mathrm{H}$ and pure Holstein cows.
\end{abstract}

Key words: crossbreeding, feed efficiency, body condition score, body weight

Received February 12, 2008.

Accepted May 21, 2008.

${ }^{1}$ Corresponding author: hein0106@umn.edu

\section{INTRODUCTION}

Crossbreeding of dairy cattle is a topic of growing interest because of dairy producers' concerns regarding heifer and cow fertility, cow health, and calf survival (Funk, 2006). In a survey by Weigel and Barlass (2003), dairy producers indicated crossbreeding improved the fertility, survival, and profitability of dairy cows.

Recent research has documented the effects of crossbreeding in dairy cattle (Heins et al., 2006a,b,c; Auldist et al., 2007; Dechow et al., 2007; Heins et al., 2008). However, these studies have predominantly focused on production, fertility, and the productive life of crossbred versus pure Holstein cows. Numerous studies have compared pure Jersey and pure Holstein cows for BW and feed intake (Dickinson et al., 1969; Blake et al., 1986; Rastani et al., 2001); however, very little research has compared crossbred and pure Holstein cows for BW, BCS, feed intake, and feed efficiency (FE).

Touchberry and Batra (1976) reported that Guernsey $\times$ Holstein crossbred cows had lower BW than did pure Holstein cows. McDowell and McDaniel (1968) reported that Brown Swiss $\times$ Holstein and Ayrshire $\times$ Brown Swiss crossbred cows tended to have higher BCS than pure Holstein cows. In Australia, Jersey $\times$ Holstein crossbred $(\mathbf{J} \times \mathbf{H})$ cows had $40 \mathrm{~kg}$ less BW than did pure Holstein cows; however, crossbred cows had higher BCS than did pure Holstein cows (Auldist et al., 2007).

McDowell and McDaniel (1968) reported that Ayrshire $\times$ Holstein and Brown Swiss $\times$ Holstein crossbred cows were generally superior to pure Holstein cows for 3 alternative measures of $\mathrm{FE}$ (therms of energy produced/therms of energy consumed, FCM/therms of net energy consumed, and protein production/feed protein intake). In a study at Agriculture Canada, Wang et al. (1992) found that Ayrshire $\times$ Holstein crossbred cows had similar FE to pure Holstein cows. In a Swiss study, $\mathrm{J} \times \mathrm{H}$ cows had significantly less net energy intake than pure Holstein cows; however, $\mathrm{J} \times \mathrm{H}$ cows were more feed efficient than pure Holstein cows (Schwager-Suter et al., 2001). 
A recent study of a Wisconsin commercial dairy compared the DMI and FE for a pen of $\mathrm{J} \times \mathrm{H}$ and pure Jersey cows and for a pen of pure Holstein cows (Anderson et al., 2007). Mean BW was $93 \mathrm{~kg}$ less for the combined $\mathrm{J} \times \mathrm{H}$ and pure Jersey cows than for the pure Holstein cows; however, BCS were similar for the 2 groups. The $\mathrm{J} \times \mathrm{H}$ and pure Jersey cows consumed $2.2 \mathrm{~kg}$ less DMI, but they also had lower production of ECM than did the pure Holstein cows. In addition, González-Verdugo et al. (2005) reported that both $\mathrm{J} \times \mathrm{H}$ and pure Holstein cows on pasture consumed similar amounts of DMI.

The objectives of this study were to determine differences between $\mathrm{J} \times \mathrm{H}$ cows and pure Holstein cows during the first $150 \mathrm{~d}$ of first lactation for BW, BCS, DMI, and $\mathrm{FE}$ in a confinement dairy facility at the University of Minnesota.

\section{MATERIALS AND METHODS}

\section{Experimental Design}

The dairy facility on the St. Paul campus of the University of Minnesota has 90 tie stalls, and the West Central Research and Outreach Center, Morris, has 150 cows in a low-input grazing environment. These 2 locations shared a study to compare crossbred and pure Holstein cattle. Crossbreeding began in December 2000 with the mating of $50 \%$ of the pure Holstein cows and heifers at both locations to Jersey AI bulls and the other $50 \%$ to Holstein AI bulls. Heifers and cows at both locations were paired by age and sire, and one member of each pair was randomly assigned to 1 of the 2 breeding groups. Jersey bulls were randomly mated to Holstein heifers and cows, but inbreeding coefficients were not allowed to surpass $6.25 \%$ for matings of Holstein heifers and cows with Holstein bulls.

Jersey and Holstein service sires were selected based on high Net Merit within breed, and 3 sires were selected per year from each breed. Both locations breed cattle seasonally; cows at St. Paul calve in the fall, and cows at Morris calve mostly in the spring, with some calving in the fall. All virgin heifers are reared and bred at Morris, which is a low-input environment. The mating design was used for 2 years, and all resulting $\mathrm{J} \times \mathrm{H}$ heifers and cows were mated to Montbeliarde AI bulls, and their pure Holstein contemporaries were mated to Holstein AI bulls.

\section{Data}

A subset of cows from the study by Heins et al. (2008) were used for the analysis of BW, BCS, DMI, and FE; however, only cows that calved for the first time at St. Paul were studied. Cows at Morris are not housed in a tie-stall barn; therefore, collection of daily feed intake was not feasible. At St. Paul, $26 \mathrm{~J} \times \mathrm{H}$ and 19 pure Holstein cows calved for the first time from October 2004 to January 2005. Two J $\times \mathrm{H}$ cows died from calving injury, and 2 pure Holstein cows were culled at 28 and $46 \mathrm{~d}$ postpartum because of gangrene mastitis and were removed from the study. Therefore, $24 \mathrm{~J} \times \mathrm{H}$ and 17 pure Holstein cows that calved for the first time at $24.4( \pm 1.0)$ mo and $25.1( \pm 2.1)$ mo of age, respectively, remained for comparison. Calving difficulty was not significantly different for the 2 breed groups. For both breed groups, 6 AI bulls had daughters represented in the study.

All cows were fed the same TMR, and the ration contained $62.8 \%$ DM. The TMR consisted of $14.8 \%$ chopped alfalfa hay, $35.0 \%$ corn silage, $26.5 \%$ protein mix, $15.5 \%$ ground corn, $5.2 \%$ roasted soybeans, and $3.0 \%$ molasses. The protein mix composition was $34.3 \%$ soybean meal, $26.7 \%$ soybean hulls, $22.9 \%$ distillers dried grains with solubles, $12.3 \%$ vitamins and minerals, and $3.8 \%$ blood meal. The TMR was fed twice daily with a Calan Data Ranger (American Calan, Northwood, $\mathrm{NH}$ ), and feed refusals were collected once daily. Feed intake and refusals were collected on cows from 4 to $150 \mathrm{~d}$ postpartum.

\section{$B W$ and $B C S$}

The BW and BCS were recorded during the evening milking every other week during the first $150 \mathrm{~d}$ postpartum. With data spanning $150 \mathrm{~d}$, each cow had BW and BCS recorded 10 times at 14-d intervals (1 to $15 \mathrm{~d}$, 16 to $30 \mathrm{~d}$, 31 to $45 \mathrm{~d}$, etc.). The BW was recorded on individual cows by using a digital scale as cows exited the milking parlor, and the BCS was measured by the same person throughout the study on a 1 to 5 scale, with $1=$ excessively thin and $5=$ excessively fat, in increments of 0.25 (Wildman et al., 1982).

Independent variables for statistical analysis of BW and BCS were the fixed effects of age at calving, breed group, and 14-d period nested within breed group. The MIXED procedure of SAS (SAS Institute, 2004) was used, with cow nested within breed as a random variable with repeated measures. The autoregressive covariance $[\mathrm{AR}(1)]$ structure was used because it resulted in the lowest Akaike's information criterion (Littell et al., 1998).

\section{Production}

Actual milk $(\mathrm{kg})$, fat $(\mathrm{kg})$, and protein $(\mathrm{kg})$ production from twice daily milking during the first $150 \mathrm{~d}$ of first lactation was calculated with Best Prediction (BP), which was implemented by the Animal Improvement 
Programs Laboratory in February 1999 for national genetic evaluation in the United States (VanRaden, 1997). Test-day observations from DHI were used to estimate production for the 4th to 150th day of lactation to be consistent with DMI, which was not recorded for the first $3 \mathrm{~d}$ of lactation. The BP adjusted for age at calving and predicted individual daily production from observed test-day production (Cole and VanRaden, 2007).

Standard edits were applied to test-day observations for production and were similar to those used by the USDA for routine genetic evaluation, and are described in Heins et al. (2006c). Each test day had an observation for milk, fat, and protein production. Estimated daily production of milk, fat, and protein for each cow was summed for DIM from the 4th to 150th day of lactation, which resulted in 147-d production records for all cows. In addition, ECM for each cow was calculated (Tyrrell and Reid, 1965), with ECM $(\mathrm{kg})=[0.327 \times($ milk kg) $]+$ $[12.96 \times($ fat kg) $]+[7.2 \times($ protein $\mathrm{kg})]$.

Age at calving and breed group were fixed effects for statistical analysis of milk, fat, protein, fat plus protein, and ECM from the 4th to 150th day postpartum of first lactation. The GLM procedure of SAS (SAS Institute, 2004) was used to obtain solutions and conduct the ANOVA.

\section{$D M I$ and FE}

Daily DMI was collected for cows from the 4th to 150 th day postpartum. The DMI were averaged for weeks (7-d periods). With data spanning $147 \mathrm{~d}$, each cow had feed intakes recorded for 21 periods (4 to $10 \mathrm{~d}$, 11 to $17 \mathrm{~d}, 18$ to $24 \mathrm{~d}$, etc.).

Fixed effects for the statistical analysis of DMI were age at calving, breed group, and 7-d period nested within breed group, and the MIXED procedure of SAS (SAS Institute, 2004) was used, with cow nested within breed as a random variable with repeated measures. Once again, the autoregressive covariance [AR(1)] structure was used because it resulted in the lowest Akaike's information criterion (Littell et al., 1998).

Two measures of feed efficiency were used to compare $\mathrm{J} \times \mathrm{H}$ and pure Holstein cows. The $\mathbf{F E}_{\mathbf{F P}}$ was the ratio of 147-d fat plus protein production $(\mathrm{kg})$ divided by 147-d DMI (kg), and the $\mathbf{F E}_{\mathrm{EN}}$ was the ratio of 147-d ECM (kg) divided by 147-d DMI (kg). Total DMI was the sum for daily DMI from the 4th to 150th day postpartum for each cow. Age at calving and breed group were fixed effects for statistical analysis of total DMI, $\mathrm{FE}_{\mathrm{FP}}$, and $\mathrm{FE}_{\mathrm{EN}}$ from the 4 th to 150 th day postpartum of first lactation. The GLM procedure of SAS (SAS Institute, 2004) was used to obtain solutions and conduct the ANOVA.

\section{RESULTS AND DISCUSSION}

\section{$B W$ and $B C S$}

Age at calving and 14-d period nested within breed group significantly $(P<0.01)$ explained variation in BW. The solution for linear regression of age at calving (16.9 \pm 3.8$)$ indicated that older cows at calving had greater BW. Least squares means, standard errors of means, and standard deviations for BW for each 14-d period and across the $150 \mathrm{~d}$ are given in Table 1. Across the $150 \mathrm{~d}$, the $\mathrm{J} \times \mathrm{H}$ cows had $33 \mathrm{~kg}$ less $\mathrm{BW}(P<0.01)$ than the pure Holstein cows (467 vs. $500 \mathrm{~kg})$.

Within each 14 -d period, $\mathrm{J} \times \mathrm{H}$ cows had significantly less $(P<0.05) \mathrm{BW}$ than pure Holstein cows (Table 1$)$. The difference in BW of $\mathrm{J} \times \mathrm{H}$ cows compared with pure Holstein cows ranged from $30 \mathrm{~kg}$ for the 4 th period to $38 \mathrm{~kg}$ for the $7 \mathrm{th}$ period. The BW change was similar for $\mathrm{J} \times \mathrm{H}$ versus pure Holstein cows from the beginning to the end of the study (+16.8 vs. $+19.7 \mathrm{~kg}$, respectively). The BW decreased slightly at the beginning of lactation for cows and then increased steadily for both $\mathrm{J} \times \mathrm{H}$ and pure Holstein cows through the 10th period.

Results for BW are consistent with the results of Auldist et al. (2007), who reported that $\mathrm{J} \times \mathrm{H}$ cows had $40 \mathrm{~kg}$ less BW than did pure Holstein cows. Touchberry and Batra (1976) reported that Guernsey $\times$ Holstein crossbred cows had less BW than did pure Holstein cows; moreover, they found that both Guernsey $\times$ Holstein crossbred cows and pure Holstein cows decreased in BW early in lactation, but had a steady increase in BW through the first $150 \mathrm{~d}$ of lactation.

For BCS, only 14-d period nested within breed significantly $(P<0.01)$ explained variation. Table 2 shows least squares means, standard errors of means, and standard deviations for BCS across the $150 \mathrm{~d}$ and for each 14-d period. The BCS were relatively low at calving because the first-lactation cows in this study were grown on pasture without energy supplementation for the summer before fall calving. For the mean of the 14-d periods, $\mathrm{J} \times \mathrm{H}$ cows had significantly $(P<0.01)$ greater BCS than did pure Holstein cows (2.90 vs. 2.76, respectively). Furthermore, $\mathrm{J} \times \mathrm{H}$ cows had significantly $(P<0.05)$ greater BCS than did pure Holstein cows at periods $1,2,3,4$, and 6 , with a tendency $(P<0.10)$ for $\mathrm{J} \times \mathrm{H}$ cows to have higher BCS than pure Holstein cows for periods $5,7,8$, and 10 . The breed groups did not differ for BCS for period 9.

Both $\mathrm{J} \times \mathrm{H}$ and pure Holstein cows decreased in BCS at the beginning of lactation (Table 2), which suggests cows were mobilizing body fat to meet the demands of production (Britt et al. 2003). Furthermore, the BCS of $\mathrm{J} \times \mathrm{H}$ cows plateaued earlier than the BCS of pure Holstein cows. 
Table 1. Least squares means, standard errors of means, and standard deviations for BW $(\mathrm{kg})$ of cows during the first $150 \mathrm{~d}$ of first lactation for breed groups

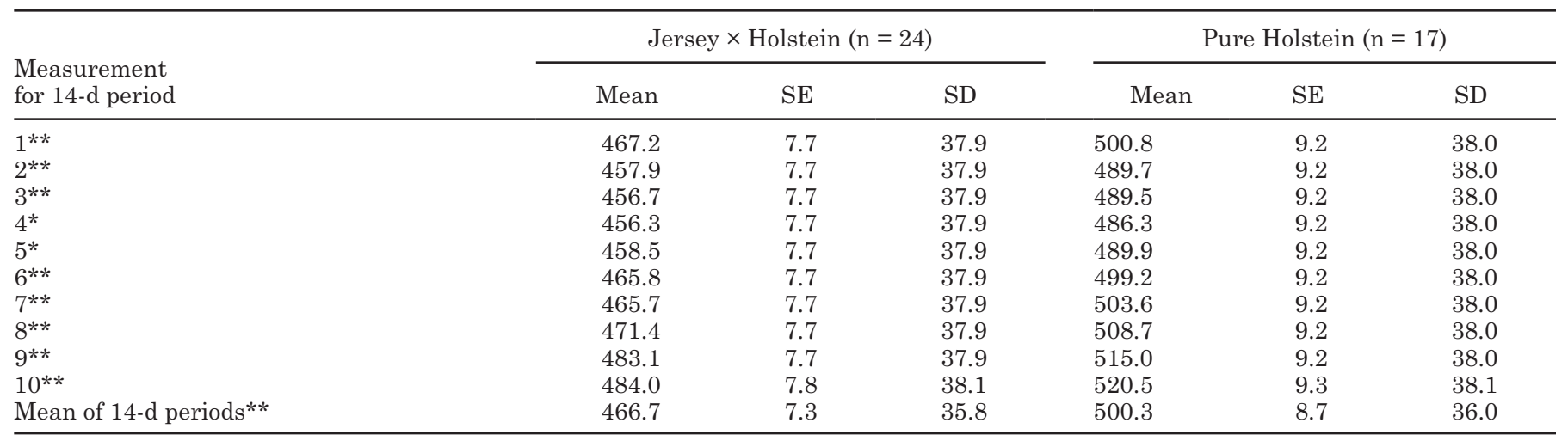

${ }^{*} P<0.05$ and ${ }^{* *} P<0.01$ for difference of breed groups.

Washburn et al. (2002) reported that pure Jersey cows had greater BCS than did pure Holstein cows (2.96 vs. 2.70); however, Rastani et al. (2001) found no significant differences between pure Jersey and Holstein cows for BCS. In agreement with the present study, Auldist et al. (2007) and Heins et al. (2008) reported that $\mathrm{J} \times \mathrm{H}$ cows had greater BCS than did pure Holstein cows.

\section{Production}

Table 3 gives least squares means, standard errors of means, and standard deviations of $\mathrm{J} \times \mathrm{H}$ and pure Holstein cows for 147-d milk, fat, and protein production, fat plus protein production, FCM, and ECM. Age at calving significantly $(P<0.05)$ influenced all traits. The $\mathrm{J} \times \mathrm{H}$ cows tended to have significantly $(P<0.10)$ less 147 -d milk volume (4,388 vs. $4,644 \mathrm{~kg})$ than pure Holstein cows. However, $\mathrm{J} \times \mathrm{H}$ cows were not significantly different $(P>0.10)$ from pure Holstein cows for 147-d fat (170 vs. $172 \mathrm{~kg}), 147-\mathrm{d}$ protein (132 vs. 137 $\mathrm{kg}$ ), and 147-d fat plus protein (302 vs. $309 \mathrm{~kg}$ ) production. Furthermore, $\mathrm{J} \times \mathrm{H}$ cows were similar $(P>0.32)$ to pure Holstein cows for 147 -d ECM (4,590 vs. 4,732 kg). Auldist et al. (2007) found that $\mathrm{J} \times \mathrm{H}$ cows had significantly less milk volume than pure Holstein cows, but breed groups did not differ for fat or protein production. Heins et al. (2008) reported that $\mathrm{J} \times \mathrm{H}$ cows had significantly less 305 -d milk (7,147 vs. $7,705 \mathrm{~kg}$ ), 305-d protein (223 vs. $238 \mathrm{~kg}$ ), and 305-d fat plus protein (497 vs. $515 \mathrm{~kg}$ ) production than pure Holstein cows in first lactation; however, breed groups were not significantly different for $305-d$ fat (274 vs. $277 \mathrm{~kg}$ ) production.

\section{$D M I$ and FE}

Both age at calving $(P<0.05)$ and 7 -d period nested within breed group $(P<0.01)$ significantly explained variation in weekly DMI. The solution for linear regression of age at calving $(0.48 \pm 0.24)$ for the mean of weekly DMI indicated that older cows at calving had greater DMI. Least squares means, standard errors of

Table 2. Least squares means, standard errors of means, and standard deviations for BCS of cows during the first $150 \mathrm{~d}$ of first lactation for breed groups

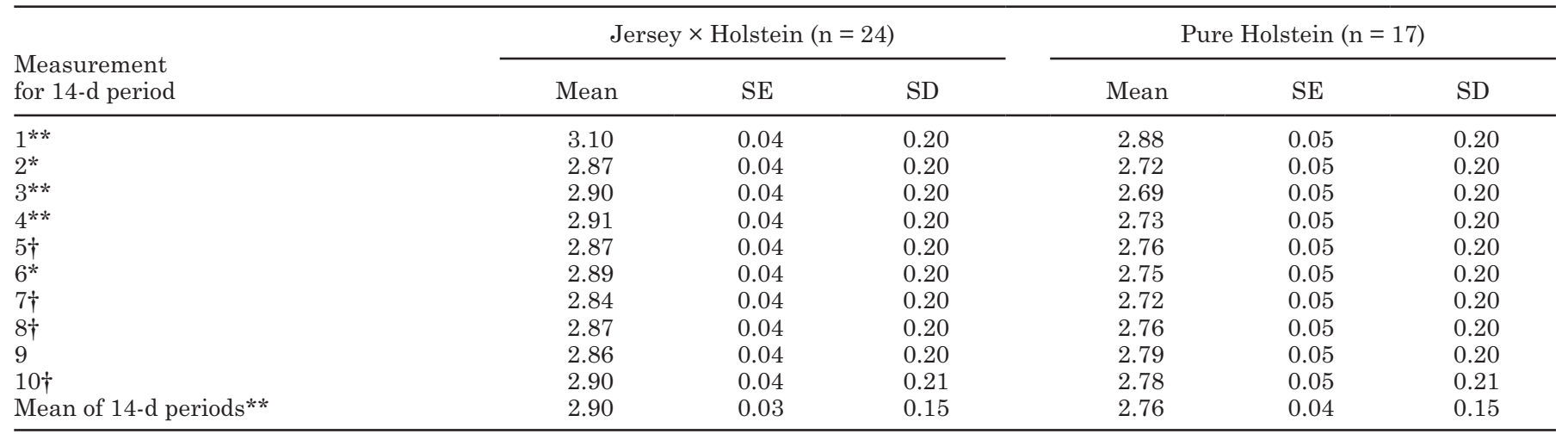

$\dagger P<0.10$; ${ }^{*} P<0.05$; and ${ }^{* *} P<0.01$ for the difference in breed groups. 
Table 3. Least squares means, standard errors of means, and standard deviations for milk, fat, and protein production, and ECM of cows from the 4th to 150th day postpartum of first lactation for breed groups

\begin{tabular}{|c|c|c|c|c|c|c|}
\hline \multirow[b]{2}{*}{ Trait } & \multicolumn{3}{|c|}{ Jersey $\times$ Holstein $(n=24)$} & \multicolumn{3}{|c|}{ Pure Holstein $(n=17)$} \\
\hline & Mean & SE & $\mathrm{SD}$ & Mean & $\mathrm{SE}$ & $\mathrm{SD}$ \\
\hline Fat, kg & 170 & 4 & 18 & 172 & 4 & 18 \\
\hline Protein, kg & 132 & 3 & 13 & 137 & 3 & 13 \\
\hline Fat plus protein, $\mathrm{kg}$ & 302 & 6 & 29 & 309 & 7 & 29 \\
\hline $\mathrm{ECM}, \mathrm{kg}$ & 4,590 & 89 & 434 & 4,732 & 106 & 436 \\
\hline
\end{tabular}

$\dagger P<0.10$ for the difference in breed groups.

means, and standard deviations of weekly DMI for the 4 th to 150 th day postpartum by breed group are given in Table 4 . The $\mathrm{J} \times \mathrm{H}$ cows did not differ $(P>0.10)$ from the pure Holstein cows for DMI during any period postpartum. The DMI rapidly increased for both breed groups from the 1st to 15 th period postpartum. For the 15th period, DMI appeared to plateau at 25 to $26 \mathrm{~kg} / \mathrm{d}$ (Table 4). The $\mathrm{J} \times \mathrm{H}$ cows $(22.0 \mathrm{~kg})$ did not differ $(P>0.30)$ from the pure Holstein cows $(22.7 \mathrm{~kg})$ for mean weekly DMI, and the $\mathrm{J} \times \mathrm{H}$ and pure Holstein cows consumed similar DMI as a percentage of BW (4.7 vs. $4.5 \%$, respectively). Anderson et al. (2007) had somewhat lower DMI as a percentage of BW, at 4.3 versus $4.0 \%$ for $\mathrm{J} \times \mathrm{H}$ and pure Jersey cows and pure Holstein cows, respectively.

Results for the DMI of pure Holstein cows in this study are similar to those reported by Rastani et al. (2001) and Britt et al. (2003), who found that pure Hol- steins consumed 22 to $23 \mathrm{~kg}$ of DMI daily in early lactation. Lee et al. (1989) reported some heterosis for total digestible nutrients consumed for crossbred Ayrshire and Holstein cows compared with pure Holstein cows.

Table 5 shows least squares means, standard errors of means, and standard deviations of $\mathrm{J} \times \mathrm{H}$ and pure Holstein cows for total DMI (as opposed to weekly DMI), $\mathrm{FE}_{\mathrm{FP}}$, and $\mathrm{FE}_{\mathrm{EN}}$ from the 4th to 150th day postpartum. Age at calving tended $(P<0.10)$ to affect only total DMI. The $\mathrm{J} \times \mathrm{H}$ cows $(3,233 \mathrm{~kg})$ were not significantly $(P>0.42)$ different from the pure Holstein cows $(3,326$ $\mathrm{kg}$ ) for total DMI from the 4th to 150th day postpartum of first lactation. Furthermore, $\mathrm{J} \times \mathrm{H}$ and pure Holstein cows did not differ $(P>0.88)$ for $\mathrm{FE}_{\mathrm{FP}}(0.094$ vs. 0.093$)$ or $\mathrm{FE}_{\mathrm{EN}}$ (1.43 vs. 1.43). Therefore, $\mathrm{J} \times \mathrm{H}$ cows produced similar amounts of fat plus protein $(\mathrm{kg})$ and ECM per kilogram of DMI consumed compared with pure Hol-

Table 4. Least squares means, standard errors of means, and standard deviations for DMI (kg) of cows from the 4th to 150 th day postpartum of first lactation for breed groups ${ }^{1}$

\begin{tabular}{|c|c|c|c|c|c|c|}
\hline 7-d period & \multicolumn{3}{|c|}{ Jersey $\times$ Holstein $(n=24)$} & \multicolumn{3}{|c|}{ Pure Holstein $(\mathrm{n}=17)$} \\
\hline 1 & 14.2 & 0.59 & 2.89 & 14.7 & 0.70 & 2.90 \\
\hline 3 & 17.4 & 0.59 & 2.89 & 17.0 & 0.70 & 2.90 \\
\hline 4 & 18.3 & 0.59 & 2.89 & 18.4 & 0.70 & 2.90 \\
\hline 5 & 19.2 & 0.59 & 2.89 & 19.8 & 0.70 & 2.90 \\
\hline 8 & 21.3 & 0.59 & 2.89 & 22.4 & 0.70 & 2.90 \\
\hline 9 & 21.7 & 0.59 & 2.89 & 23.3 & 0.70 & 2.90 \\
\hline 10 & 22.3 & 0.59 & 2.89 & 23.2 & 0.70 & 2.90 \\
\hline 11 & 22.7 & 0.59 & 2.89 & 23.7 & 0.70 & 2.90 \\
\hline 12 & 23.0 & 0.59 & 2.89 & 23.8 & 0.70 & 2.90 \\
\hline 13 & 23.7 & 0.59 & 2.89 & 24.2 & 0.70 & 2.90 \\
\hline 14 & 24.6 & 0.59 & 2.89 & 24.9 & 0.70 & 2.90 \\
\hline 20 & 25.2 & 0.59 & 2.89 & 25.9 & 0.70 & 2.90 \\
\hline 21 & 25.0 & 0.59 & 2.89 & 25.8 & 0.70 & 2.90 \\
\hline Mean of $7-d$ periods & 22.0 & 0.47 & 2.29 & 22.7 & 0.56 & 2.30 \\
\hline
\end{tabular}

${ }^{1} P>0.10$ for all differences of breed groups. 
Table 5. Least squares means, standard errors of means, and standard deviations for total DMI and 2 measures of feed efficiency from the 4th to 150th day postpartum of first lactation for breed groups

\begin{tabular}{|c|c|c|c|c|c|c|}
\hline Trait $^{1}$ & \multicolumn{3}{|c|}{ Jersey $\times$ Holstein $(n=24)$} & \multicolumn{3}{|c|}{ Pure Holstein $(n=17)$} \\
\hline $\begin{array}{l}\text { Total DMI, }{ }^{2} \mathrm{~kg} \\
\mathrm{FE}_{\mathrm{FP}}{ }^{3} \\
\mathrm{FE}_{\mathrm{EN}}{ }^{3}\end{array}$ & $\begin{array}{c}3,233 \\
0.094 \\
1.43\end{array}$ & $\begin{array}{l}72 \\
0.002 \\
0.02\end{array}$ & $\begin{array}{l}353 \\
0.007 \\
0.1134\end{array}$ & $\begin{array}{c}3,326 \\
0.093 \\
1.43\end{array}$ & $\begin{array}{l}86 \\
0.002 \\
0.03\end{array}$ & $\begin{array}{l}355 \\
0.007 \\
0.1139\end{array}$ \\
\hline
\end{tabular}

${ }^{1} \mathrm{FE}_{\mathrm{FP}}=$ fat plus protein/DMI; $\mathrm{FE}_{\mathrm{EN}}=\mathrm{ECM} / \mathrm{DMI}$.

${ }^{2} P>0.42$.

${ }^{3} P>0.88$

stein cows. The measures of FE used in this study do not partition energy into the alternative components for production, body maintenance, growth, or restoration of body reserves. The potential for the $\mathrm{J} \times \mathrm{H}$ cows to devote less energy to body maintenance and growth, but more energy to restoration of body reserves, could perhaps account for the enhanced fertility and health of crossbreds in many studies. The results are in agreement with those of Wang et al. (1992), who reported that crossbred cows had FE (milk production/total digestible nutrients) similar to that of pure Holstein cows; however, Schwager-Suter et al. (2001) found that $\mathrm{J} \times \mathrm{H}$ cows had more FE (energy content of milk/net energy intake) than did pure Holstein cows.

\section{CONCLUSIONS}

Many dairy producers have turned to crossbreeding to reduce calving difficulty and stillbirths of cows and to improve the health, fertility, and productive life of cows. However, dairy producers should consider BW, $\mathrm{BCS}, \mathrm{DMI}$, and $\mathrm{FE}$ when selecting among alternative dairy breeds for a crossbreeding system.

In this study, $\mathrm{J} \times \mathrm{H}$ cows had $33 \mathrm{~kg}$ less $\mathrm{BW}$ and greater BCS than did pure Holstein cows during the first $150 \mathrm{~d}$ of first lactation. Furthermore, the $\mathrm{J} \times \mathrm{H}$ cows in this study were not different from pure Holstein cows for any measure of production, except for fluid volume and for DMI from the 4th to 150th day postpartum for first lactation. Therefore, $\mathrm{J} \times \mathrm{H}$ cows also had similar FE compared with pure Holstein cows during roughly the first half of lactation.

Some might expect $\mathrm{J} \times \mathrm{H}$ cows to consume less DMI than pure Holstein cows because of their similar production but smaller BW; however, this study suggests the DMI of $\mathrm{J} \times \mathrm{H}$ cows was similar to that of pure Holsteins. Apparently, $\mathrm{J} \times \mathrm{H}$ cows used DMI beyond their needs for production and body maintenance to achieve greater BCS.

The data for this study were recorded in a single herd with a small sample size; therefore, additional research with greater numbers of cows in varied environments is needed to fully compare crossbred vs. pure Holstein cows for BW, BCS, DMI, and FE. In addition, this study investigated only the first $150 \mathrm{~d}$ of first lactation, and additional research is needed comparing multiple 305d lactations of crossbred versus pure Holstein cows for BW, BCS, DMI, and FE. Assessment of total economic merit of $\mathrm{J} \times \mathrm{H}$ versus pure Holstein cows must include BW, BCS, DMI, production, and FE, as well as many other factors such as calving difficulty, stillbirth, fertility, health, survival, and salvage value of cows.

\section{ACKNOWLEDGMENTS}

The authors express appreciation to John Cole at USDA-Animal Improvement Programs Laboratory (Beltsville, MD) for the use of the Best Prediction program. The authors also express gratitude to Bill Hansen and coworkers at the St. Paul dairy facility for their assistance in data collection and the care of animals. Funds for this research were provided by the American Jersey Cattle Club Research Foundation (Reynoldsburg, OH).

\section{REFERENCES}

Anderson, T., R. Shaver, P. Bosma, and V. DeBoer. 2007. Case study: Performance of lactating Jersey and Jersey-Holstein crossbred versus Holstein cows in a Wisconsin confinement dairy herd. Prof. Anim. Sci. 23:541-545.

Auldist, M. J., M. F. S. Pyman, C. Grainger, and K. L. Macmillan. 2007. Comparative reproductive performance and early lactation productivity of Jersey $\times$ Holstein cows in predominantly Holstein herds in a pasture-based dairying system. J. Dairy Sci. 90:48564862 .

Blake, R. W., A. A. Custodio, and W. H. Howard. 1986. Comparative feed efficiency of Holstein and Jersey cows. J. Dairy Sci. 69:1302-1308.

Britt, J. S., R. C. Thomas, N. C. Speer, and M. B. Hall. 2003. Efficiency of converting nutrient dry matter to milk in Holstein herds. J. Dairy Sci. 86:3796-3801.

Cole, J. B., and P. M. VanRaden. 2007. A manual for use of BESTPRED: A program for estimation of lactation yield and persistency using Best Prediction. Animal Improvement Programs Laboratory, Agricultural Research Service, Beltsville, MD

Dechow, C. D., G. W. Rogers, J. B. Cooper, M. I. Phelps, and A. L. Mosholder. 2007. Milk, fat, protein, and somatic cell score and 
days open among Holstein, Brown Swiss and their crosses. J. Dairy Sci. 90:3542-3549.

Dickinson, F. N., B. T. McDaniel, and R. E. McDowell. 1969. Comparative efficiency of feed utilization during first lactation of Ayrshire, Brown Swiss, and Holstein cows. J. Dairy Sci. 52:489497.

Funk, D. A. 2006. Major advances in globalization and consolidation of the artificial insemination industry. J. Dairy Sci. 89:13621368.

González-Verdugo, H., J. C. Magofke, and C. Mella. 2005. Productivity, intake and biological efficiency in New Zealand Friesian and $\mathrm{F}_{1}$ (Jersey-New Zealand Friesian) cows calved during late winter in the Xth Region, Chile. Arch. Med. Vet. 37:37-47.

Heins, B. J., L. B. Hansen, and A. J. Seykora. 2006a. Calving difficulty and stillbirths of pure Holsteins versus crossbreds of Holstein with Normande, Montbeliarde, and Scandinavian Red. J. Dairy Sci. 89:2805-2810.

Heins, B. J., L. B. Hansen, and A. J. Seykora. 2006b. Fertility and survival of pure Holsteins versus crossbreds of Holstein with Normande, Montbeliarde, and Scandinavian Red. J. Dairy Sci. 89:4944-4951.

Heins, B. J., L. B. Hansen, and A. J. Seykora. 2006c. Production of pure Holsteins versus crossbreds of Holstein with Normande, Montbeliarde, and Scandinavian Red. J. Dairy Sci. 89:27992804.

Heins, B. J., L. B. Hansen, A. J. Seykora, D. G. Johnson, J. G. Linn, J. E. Romano, and A. R. Hazel. 2008. Crossbreds of Jersey $\times$ Holstein compared to pure Holsteins for production, fertility, and body and udder measurements during first lactation. J. Dairy Sci. 91:1270-1278

Lee, A. J., L. A. Sliger, C. Y. Lin, A. J. McAllister, T. R. Batra, G. L. Roy, J. A. Vesely, J. M. Wauthy, and K. A. Winter. 1989. Feed efficiency of dairy cows during first lactation. Can. J. Anim. Sci. 69:877-889.

Littell, R. C., P. R. Henry, and C. B. Ammerman. 1998. Statistical analysis of repeated measures data using SAS procedures. J. Anim. Sci. 76:1216-1231.
McDowell, R. E., and B. T. McDaniel. 1968. Interbreed matings in dairy cattle. I. Yield traits, feed efficiency, type and rate of milking. J. Dairy Sci. 51:767-777.

Rastani, R. R., S. M. Andrew, S. A. Zinn, and C. J. Sniffen. 2001 Body composition and estimated tissue energy balance in Jersey and Holstein cows during early lactation. J. Dairy Sci. 84:12011209.

SAS Institute. 2004. SAS/STAT Software, Release 9.1.3. SAS Inst. Inc., Cary, NC.

Schwager-Suter, R., C. Stricker, D. Erdin, and N. Kunzi. 2001. Net efficiencies of Holstein, Jersey, and $\mathrm{F}_{1}$-crosses. Anim. Sci. 72:335-342.

Touchberry, R. W., and T. R. Batra. 1976. Body weight changes in lactating purebred and crossbred dairy cattle. J. Dairy Sci 59:733-743.

Tyrrell, H. F., and J. T. Reid. 1965. Prediction of the energy value of cow's milk. J. Dairy Sci. 48:1215-1223.

VanRaden, P. M. 1997. Lactation yields and accuracies computed from test day yields and (co)variances by best prediction. J. Dairy Sci. 80:3015-3022.

Wang, S., G. L. Roy, A. J. Lee, A. J. McAllister, T. R. Batra, C. Y. Lin, J. A. Vesely, J. M. Wauthy, and K. A. Winter. 1992. Evaluation of various measures of and factors influencing feed efficiency of dairy cattle. J. Dairy Sci. 75:1273-1280.

Washburn, S. P., S. L. White, J. T. Green Jr, and G. A. Benson. 2002 Reproduction, mastitis, and body condition of seasonally calved Holstein and Jersey cows in confinement or pasture systems. J. Dairy Sci. 85:105-111.

Weigel, K. A., and K. A. Barlass. 2003. Results of a producer survey regarding crossbreeding on US dairy farms. J. Dairy Sci. 86:4148-4154.

Wildman, E. E., G. M. Jones, P. E. Wagner, R. L. Boman, H. F. Troutt Jr, and T. N. Lesch. 1982. A dairy cow body condition scoring system and its relationship to selected production characteristics. J. Dairy Sci. 65:495-501. 